\title{
STATISTICAL ANALYSIS OF THE MAIN INDICATORS IN EARLY EDUCATIONAL SYSTEM IN BACAU COUNTY COMPARED TO THE CENTRAL REGION OF THE REPUBLIC OF MOLDOVA
}

\author{
Vasilica-Lăcrămioara Ciomârtan \\ Academy of Economic Studies of Moldova \\ Economist at Statistical County Directorate Bacau \\ lacri_vasi@yahoo.com
}

\begin{abstract}
An important factor in promoting economic development is the educational capital that should be seen as an investment in those who will generate economic growth. The present paper aims to carry out a statistical analysis of indicators in the field of education: early education, presentation based on statistical indicators disseminated by the two main official institutions: the National Institute of Statistics of Romania and the National Bureau of Statistics of the Republic of Moldova. In order to quantify the educational phenomenon in the two territorial units for statistics regarding the education market, a rather small number of indicators were taken into account due to lack of their dissemination on the desired administrative-territorial units.
\end{abstract}

Keywords

Education; school unit; school population; teaching staff

JEL Classification

I20; I21; C 200

\section{Introduction}

In addition to other information, the foundation of social and economic policies also requires the knowledge of some essential aspects of the educational system and its segments, as this field has obvious and defining implications on the evolution of a society. In a normal society, educational capital should underpin all social, political and economic decisions.

The main statistical indicators in educational system refer to institutions, school population (the total number of preschoolers, pupils, and students involved in the educational process regardless of the form of ownership and the levels of education), teaching staff and logistics.

Educational indicators are the basis for analyses that allow the foundation and adoption of decisions related to the conduct of economic activities, the results of policies adopted over a certain period of time and their effects.

According to the International Standard Classification of Education - ISCED 2001, early childhood and preprimary education are included in early education category level 0 , as the first stage in the educational system. The units operating at level 0 both in Romania and the Republic of Moldova are nurseries (for the institutionalization of children under the age of 3) and kindergartens (for children aged 3-5 years for Romania and 3-6 years for the Republic of Moldova).

The reduced number of indicators analysed in the present paper is mainly due to their lack of availability for the desired territorial level (county for Romania and region for the Republic of Moldova). 


\section{Short methodological presentation}

The intend was to provide a comparison between the two administrative territorial units in Romania and the Republic of Moldova concerning grouping disseminated statistical indicators according to the specific methodology. In conducting this analysis, international comparability in the field of education was taken into account, based on the International Standard Classification of Education ISCED 2011.

Thus, according to the International Standard Classification of Education 2011, the educational system of the two states is as follows:

Table 1 Comparisons of the educational system according to ISCED between Romania and the Republic of Moldova

\begin{tabular}{|c|c|c|}
\hline $\begin{array}{l}\text { Level by International } \\
\text { Standard } \\
\text { Classification of } \\
\text { Education ISCED } \\
2011\end{array}$ & $\begin{array}{l}\text { Educational system in } \\
\text { Romania }\end{array}$ & $\begin{array}{l}\text { Educational system in } \\
\text { Republic of Moldova }\end{array}$ \\
\hline Level 0 & $\begin{array}{l}\text { Early education } \\
\text { - Early childhood education } \\
\text { - Preprimary (preschool) } \\
\text { education }\end{array}$ & Early education \\
\hline Level 1 & Primary education & Primary education \\
\hline Level 2 & $\begin{array}{l}\text { Lower secondary education: } \\
\text { gymnasium }\end{array}$ & $\begin{array}{l}\text { Lower secondary education- } \\
\text { gymnasium: (grades V to IX) }\end{array}$ \\
\hline Level 3 & $\begin{array}{l}\text { Upper secondary education: } \\
\text { - high school and vocational } \\
\text { (lower cycle and upper } \\
\text { cycle) }\end{array}$ & $\begin{array}{l}\text { Upper secondary education : } \\
\text { - lyceum education (grades X- } \\
\text { XII) } \\
\text { - secondary vocational } \\
\text { education (for graduates of } \\
\text { gymnasium) } \\
\text { - postsecundary vocational } \\
\text { education (the first } 2 \text { years for } \\
\text { graduates of gymnasium) }\end{array}$ \\
\hline Level 4 & $\begin{array}{l}\text { Non-university tertiary } \\
\text { education: post high school } \\
\text { and foremen education }\end{array}$ & $\begin{array}{l}\text { Secondary vocational } \\
\text { education (for graduates of } \\
\text { general secondary schools and } \\
\text { lyceums) }\end{array}$ \\
\hline Level 5 & - & $\begin{array}{l}\text { Postsecundary vocational } \\
\text { education (exclusive the first } 2 \\
\text { years for graduates of } \\
\text { gymnasium) }\end{array}$ \\
\hline Level 6 & $\begin{array}{l}\text { Higher education - Bachelor } \\
\text { studies }\end{array}$ & $\begin{array}{l}\text { Licence's higher education } \\
\text { (cycle I) }\end{array}$ \\
\hline Level 7 & $\begin{array}{l}\text { Higher education - master's } \\
\text { degree or equivalent } \\
\text { (postgraduate studies and } \\
\text { courses) }\end{array}$ & $\begin{array}{l}\text { Master's higher education } \\
\text { (cycle II) } \\
\text { Long first degree programme } \\
\text { equivalent at level } 7 \text { (integrated } \\
\text { higher education, inclusive } \\
\text { medicine and pharmacy) }\end{array}$ \\
\hline Level 8 & $\begin{array}{l}\text { Doctoral and post-doctoral } \\
\text { studies }\end{array}$ & $\begin{array}{l}\text { Doctorate (cycle III) } \\
\text { Postdoctorate }\end{array}$ \\
\hline
\end{tabular}

Source: INS (National Institute of Statistics): Educational system in Romania and BNS (National Bureau of Statistics): Education in the Republic of Moldova - Statistical Publication 
In order to carry out the study, the most recently published indicators related to a 5-year period have been extracted from the databases of the National Institute of Statistics of Romania and the National Bureau of Statistics of the Republic of Moldova, so as to be able to follow their dynamic evolution.

The types of units functioning in Romania are nurseries and kindergartens, the latter being independent or subordinated to other educational institutions, and the units functioning in the Republic of Moldova are nurseries, kindergartens, nurserykindergartens, school-kindergartens, and community centres. These units can provide regular care program, as well as extended program, and weekly or special program, in both private and public systems.

Teaching staff are natural persons employed in the educational system that perform teaching activities within the educational and training process (full-time and part-time). According to the methodology, they have to register only once at the unit where they are employed (where the employment record book is issued).

As for the number of children enrolled in nurseries and kindergartens, there are differences between the two countries. In Romania early childhood education corresponds to level 01, according to international education regulations (the new International Standard Classification of Education - ISCED 2011) and includes children aged 0-2 years, whilst preprimary education - level 02 - includes children aged 3-5 years and over.

In the Republic of Moldova, the age groups corresponding to early education are: 0-2 years for early childhood education (level 01) and 3-6 years for preprimary education (level 02).

\section{Statistical analysis of indicators in early education (early childhood education and preprimary education)}

Early education includes early childhood education and preprimary education. The disseminated statistical indicators are: school units (nurseries and kindergartens), enrolled children, teaching staff and infrastructure related to early education.

With regard to the availability of these indicators for comparative analysis, it differs from one indicator to another. For instance, the infrastructure of the number of nurseries and kindergartens is disseminated only by the National Institute of Statistics at county level, whereas we do not have this information regarding the Central Region.

Another example is the dissemination of the indicators related to capacity of institutions (number of places, groups) by the National Bureau of Statistics of the Republic of Moldova, whereas we don't have such information at the level of the National Institute of Statistics in Romania.

At the beginning of 2017/2018, the number of units in early education in Bacau County was 435 , while at the same time, the Central Region numbered 485 units. The only year of analysis when the number of nurseries and kindergartens in Bacau County outstripped the Central Region was the beginning of 2013 (+one unit), while the highest gap between the two territorial units was recorded in 2017: (+50 units).

The dynamics of the number of nurseries and kindergartens in Bacau County follows a downward trend, inasmuch as in the last year of the analysis the number decreased by $3.1 \%$ compared to previous year, and by $9.4 \%$ compared to 2013 . The number of units registered in the Central Region follows an oscillating trend, the highest increase compared to previous year being recorded in $2014(+1.5 \%)$, while in 2017 there were $0.4 \%$ fewer nurseries and kindergartens than in 2016, but $1.3 \%$ more than in $2013(+5$ units). 


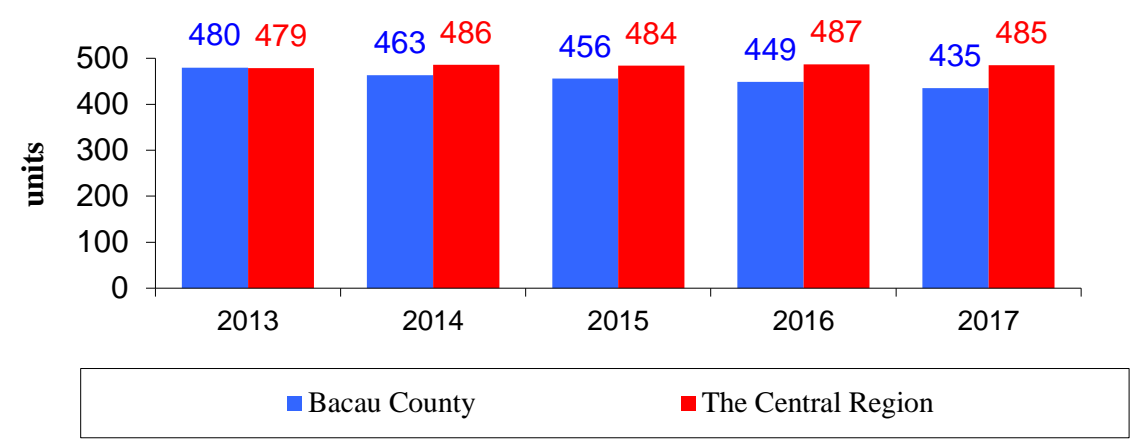

Figure1: Number of units in early education, Bacau County and the Central Region (2013-2017)

Source: database of County Statistical Direction Bacau and www.statistica.md

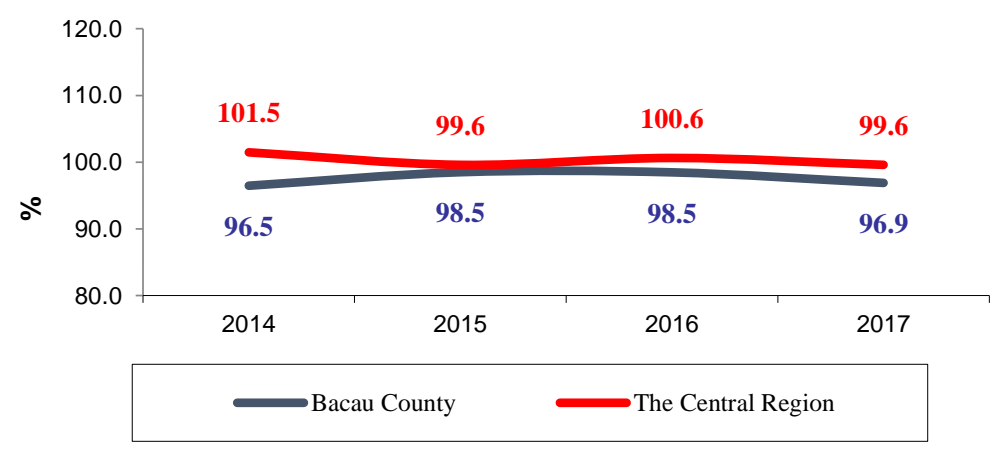

Figure 2: Dynamics of the number of units compared to previous year, Bacau County and the Central Region of the Republic of Moldova (\%)

Source: processed data from County Statistical Direction Bacau database and www.statistica.md

Taking into account age discrepancy in early education between the two educational systems: 0-5 years of age for Romania and 0-6 years of age for the Republic of Moldova, the number of children enrolled in nurseries and kindergartens can not be compared as numbers, but only as dynamics of this indicator.

While there is a decrease in the number of children attending these units from year to year in Bacau County, the situation is completely opposite for the Central Region of the Republic of Moldova where their number increases (except for the last year of the analysis). In 2017 in Bacau County they were 1.7\% fewer children institutionalized in early education system than in the previous year, while compared to 2013 their number decreased by $9.3 \%$. Although in 2017 the number of children attending nurseries and kindergartens in the Central Region decreased by $1.0 \%$ compared to 2016, when compared to 2013 , their number increased by $2.5 \%$. 


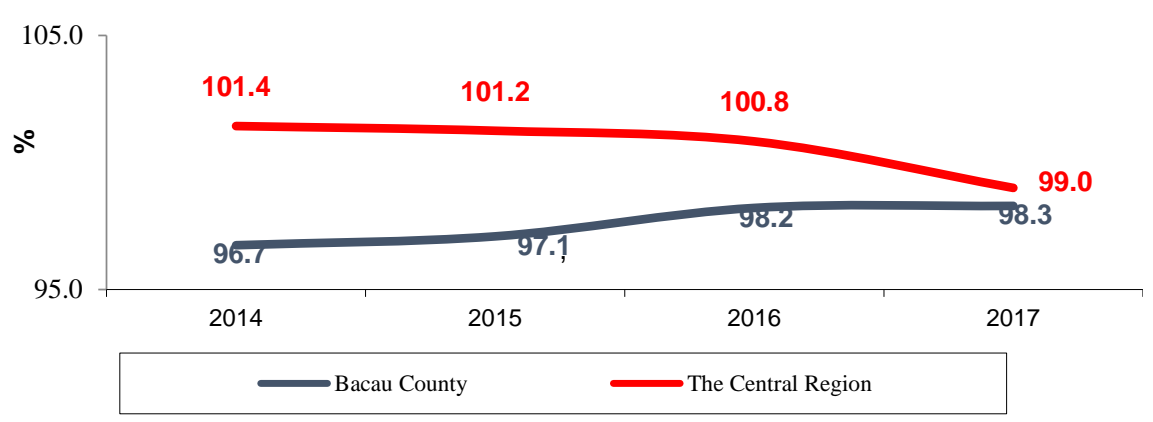

Figure 3: Dynamics of children enrolled in early education institutions compared to previous year, Bacau County and the Central Region of the Republic of Moldova, 2013-2017 (\%)

Source: processed data from www.insse.ro and www.statistica.md

The gross enrollment rate in early childhood education and preprimary education is an indicator used to highlight the level of participation in education during a given year. The proportion of enrollment in the educational process reflects the capacity of the educational system to allow children from early childhood and preprimary age groups to early education system. The calculation formula for gross enrollment rate is:

$$
R B C^{t}=\frac{E_{t}}{P_{t v}} * 100
$$

where:

$\mathrm{RBC}^{\mathrm{t}}=$ gross enrollment rate in educational system, during school year $\mathrm{t}$;

$\mathrm{E}_{\mathrm{t}}=$ total number of children enrolled in early education system, regardless of age, during school year $t$;

$\mathrm{P}_{\mathrm{tv}}=$ total population of age group $\mathrm{v}$, the official age group corresponding to early education level.

In order to calculate the gross enrollment rate in early education, the official age group for Bacau County is 0-5 years of age, and the one for the Central Region of the Republic of Moldova is 0-6 years of age.

As a percentage ratio of the population of official age group as at January 1st, the gross enrollment rates in early education system in Bacau County do not exceed $40 \%$ throughout the 2013-2017 period, with the highest rate registered in 2014 (40.1\%). Unlike the situation in Bacau County, the gross enrollment rates in early education institutions in the Central Region are increasing from one year to another, from $48.1 \%$ in 2013 to $49.3 \%$ in 2016 and 2017.

The dynamics of children enrolled in Bacau County, compared to previous year, follows the same downward trend as that of the population of official corresponding age group in early education. The decreases of the number of enrolled children in Bacau County are higher than the decreases of the population of official age group ( $0-5$ years), except for 2017, when the decrease in population compared to previous year is lower than that of the number of enrolled children (-1.7\% versus $-2.4 \%)$ and also $2014(0.4$ $\mathrm{pp}$ between the two dynamic values). In case of the Central Region, the situation is the opposite: the positive relative changes compared to previous year for children enrolled in nurseries and kindergartens are superior to the positive relative changes for population aged 0-6 years. An exception to this trend is observed in year 2017 compared to 2016, when the dynamics were negative, the decrease of the population 
aged 0-6 years being lower than the decrease of children enrolled in institutions $(-0.9 \%$ versus $-1.0 \%)$.

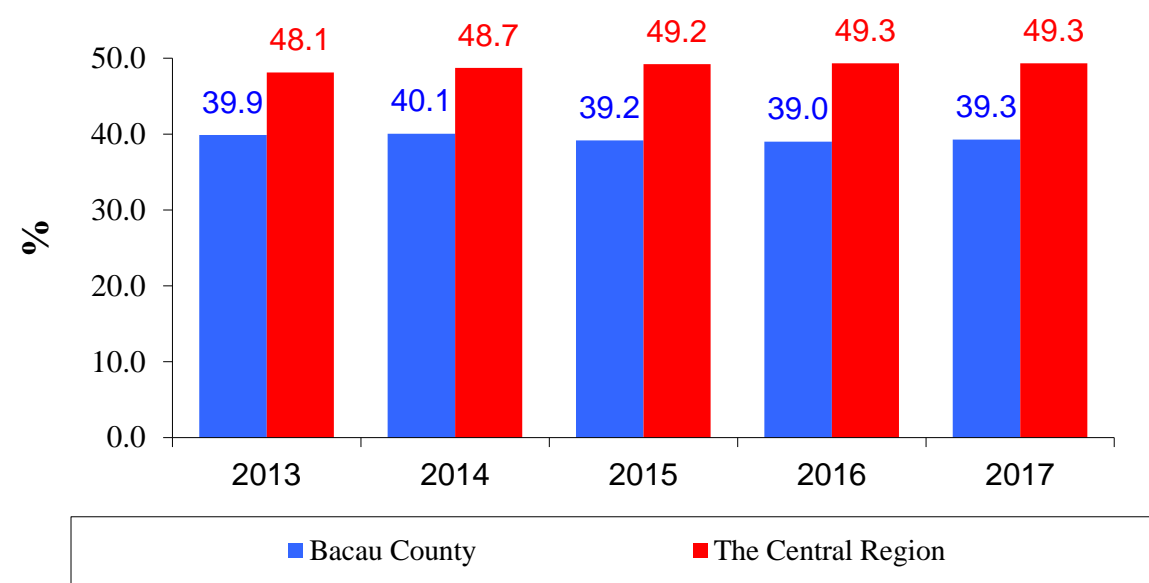

Figure 4: Gross enrollment rates in early education system, Bacau County and the Central Region of the Republic of Moldova, 2013-2017 (\%)

Source: processed data from www.insse.ro and www.statistica.md

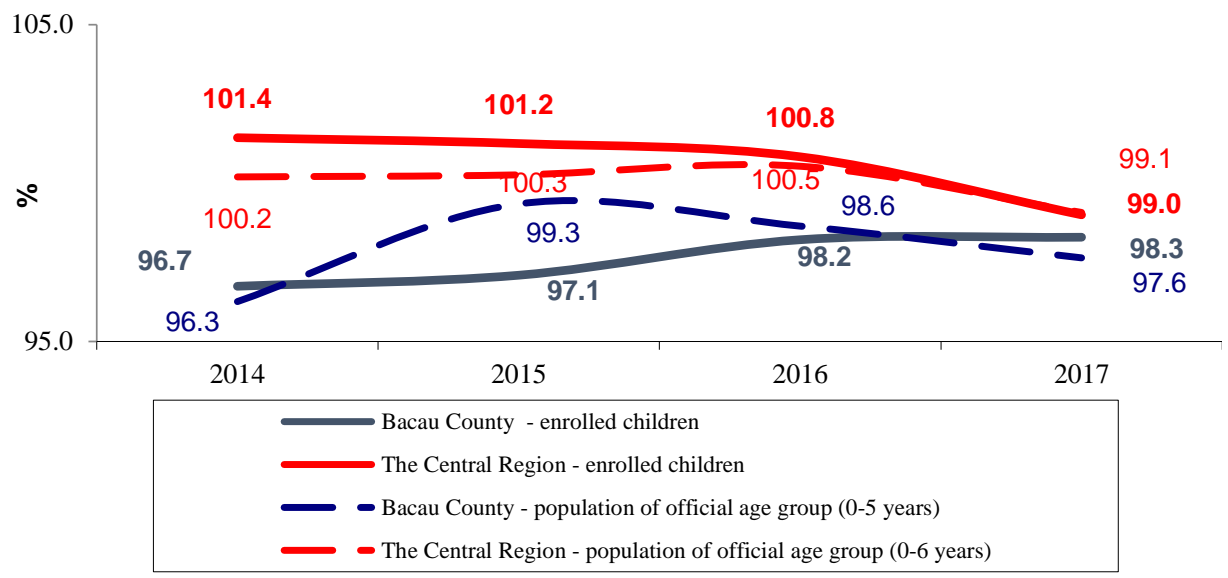

Figure 5: Dynamics of number of children enrolled in early education institutions and dynamics of population of official age group, compared to previous year, Bacau County and the Central Region of the Republic of Moldova $(\%)$

Source: processed data from www.insse.ro and www.statistica.md

When analysed on the two age groups: up to 3 years and 3 years and over, differences can be observed between the situation in Bacau County and that in the Central Region. While in 2017 early education institutions in Bacau County gathered 91.9\% of enrolled children aged over 3 years, at the same moment the Central Region gathered $89.9 \%$. For both Bacau County and the Central Region, compared to 2013, there is a tendency to change in the structure of number of enrolled children, that is increasing shares of the number of enrolled children aged up to 3 years $(+5.9$ pp for Bacau County and +1 . $6 \mathrm{pp}$ for the Central Region). 


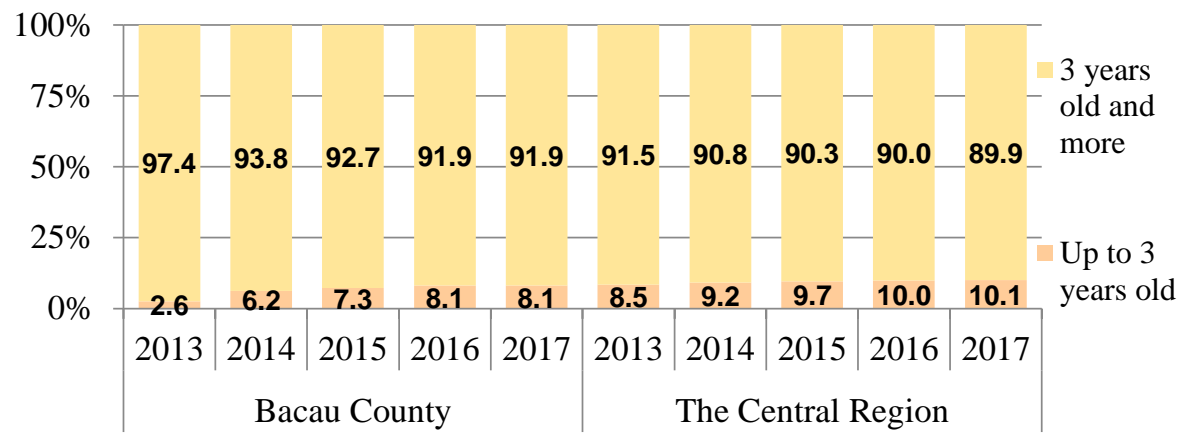

Figure 6: Evolution of the structure of number of children enrolled in early education institutions by age groups 0-3 years and 3 years and over, Bacau County and the Central Region of the Republic of Moldova (\%)

Source : processed data from County Statistical Direction Bacau database and www.statistica.md

The average unit size in early education is the ratio between the number of children and the number of units they are enrolled in. Thus, taking into account the number of operating nurseries and kindergartens, it has been noted that the average number of children per early education institution in Bacau County is 39, whereas in the Central Region of the Republic of Moldova the average number of enrolled children per unit is 90.

Unlike the National Institute of Statistics, the National Bureau of Statistics of the Republic of Moldova also disseminates the number of existing places in such institutions, therefore there were 82 children per 100 places in the 2013-2014 period and 83 children per 100 places in the years 2015 and 2017, the maximum number of 84 children per 100 places being registered in 2016.

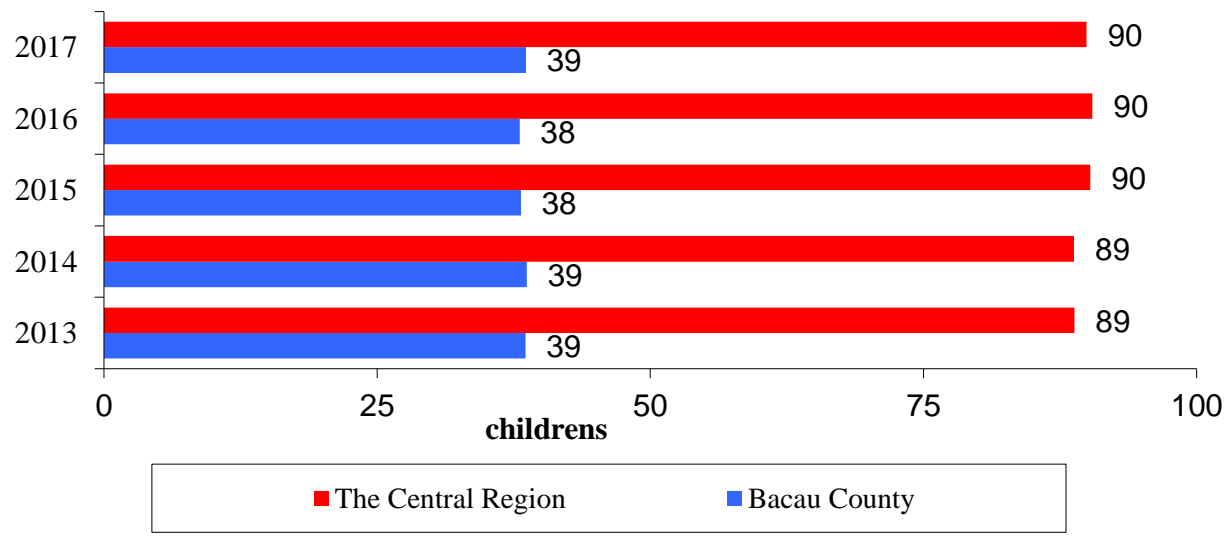

Figure 7: Average number of enrolled children per early education institution, Bacau County and the Central Region, 2013-2017 (persons)

Source : processed data from www.insse.ro and www.statistica.md

In order to have a complete and clear picture of the educational system, it is necessary for the statistical analysis to be extended also to the teaching staff, the very people directly involved in the realization and positive development of the educational process. The number of teaching stuff in early education units in Bacau County in 2017 was lower than in the Central Region, situation which remained unchanged throughout the entire analysed period. As with other indicators presented, while early education 
phenomenon in Bacau County follows a descending trend, the Central Region registers an increase over the analysed period.

The continuous decrease in the number of enrolled children and in the population of official age group corresponding to early education level in Bacau County has also determined a decrease in teaching staff from year to year. Thus, in 2017, the number of teaching staff in early education system decreases by $1.6 \%$ compared to previous year and by $7.3 \%$ when compared to 2013. Teaching staff number in the Central Region increases by $3.1 \%$ in 2017 compared to 2013 and it registers a slight decrease of $0.3 \%$ compared to previous year.

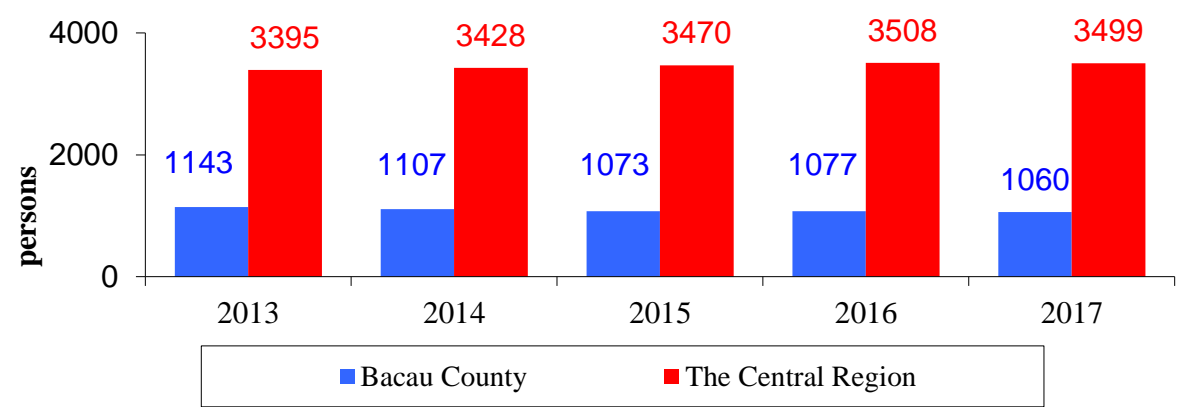

Figure 8: Teaching staff in early education institutions, Bacau County and the Central Region of the Republic of Moldova (persons)

Source: www.insse.ro and www.statistica.md

Taking into account the number of operating nurseries and kindergartens, it has been noted that the average number of teaching staff members per early education institution throughout the 2013-2017 period in Bacau County is 2, whereas in the Central Region of the Republic of Moldova the average number of teaching staff members per institution is 7 .

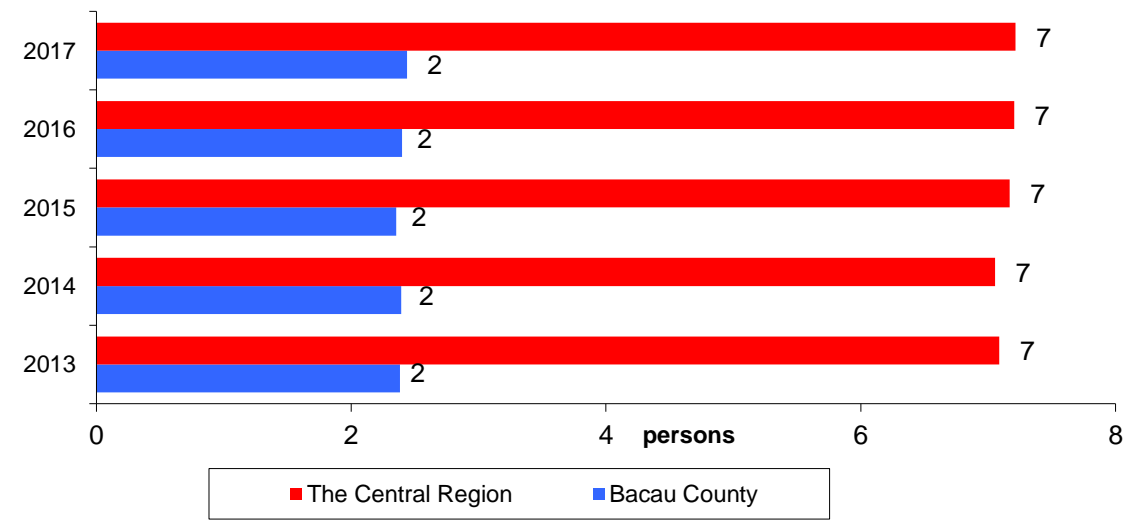

Figure 9: Average number of teaching staff per early education institution, Bacau County and the Republic of Moldova (persons)

Source: processed data from www.insse.ro and www.statistica.md

A relevant average indicator in educational statistics is the average number of children per teaching staff member. Taking into account the number of teaching staff, it has been noted that the average number of children per teaching staff member in nurseries and 
kindergartens in Bacau County throughout the 2013-2016 period is 13, while in 2017 the number is reduced to 12. In the Central Region of the Republic of Moldova there is an average number of 16 children per teaching staff member throughout the entire analysed period.

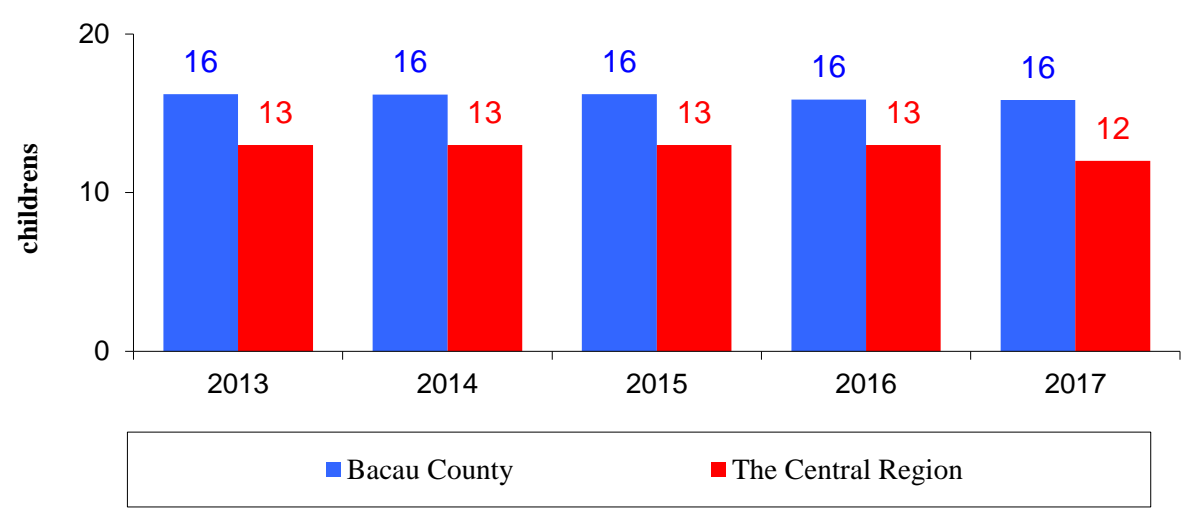

Figure 10: Average number of children per teaching staff member in early education institutions, Bacau County and the Central Region of the Republic of Moldova, 2013-2017 (persons)

Source: processed data from County Statistical Direction Bacau database and www.statistica.md

The existence of a link between the number of children enrolled in the early education institutions and the teaching staff in this education system can be determined by one of the parametric methods for determining the link, namely the regression equation. According to the available data, both for Bacau County and for the Central Region, there is a direct link between the two indicators, ie the increase of 100 children enrolled in the early education institutions in Bacau County, the number of the related teaching staff would increase average of 6 teachers, while for the Central Region of the Republic of Moldova, with the increase of 100 children, the teaching staff would increase by an average of about 8 people.
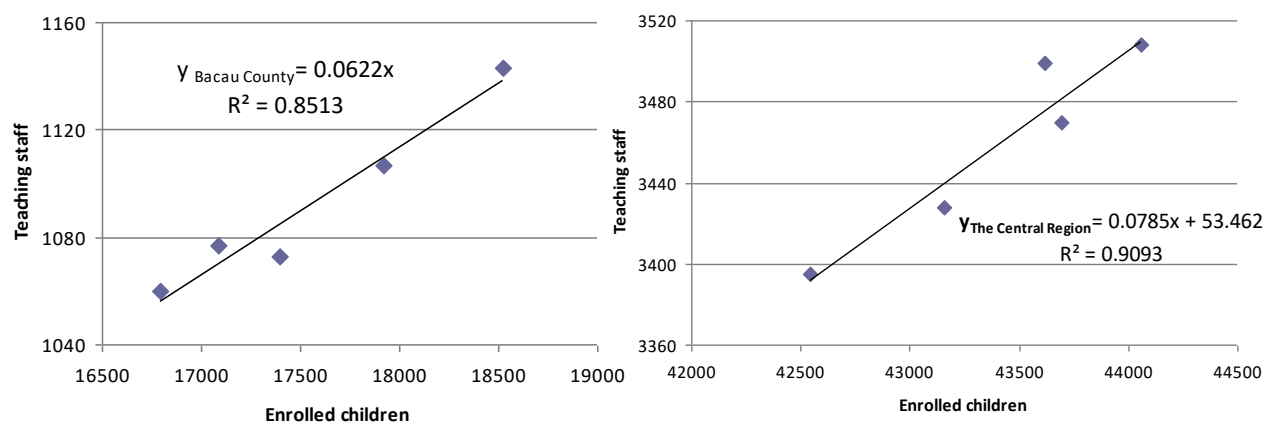

Figure 11: The existing link between the number of children enrolled in the early education institutions and the teaching staff of these institutions in Bacau County and the Central Region of the Republic of Moldova

Source: processed data from County Statistical Direction Bacau database and www.statistica.md 
The calculation of the correlation coefficient, in both cases shows a close connection between the two variables, the calculated determinant coefficient indicates a weight of $85.1 \%$ of the influence of the number of enrolled children on the teaching staff existing in the early education institutions in Bacau County, in time for the situation in the Central Region, the influence is over $90 \%$ (90.9\%).

Similarly, it can be determined what type of link exists between the population of the official age group (for Bacau County it is 0-5 years and for the Central Region of the Republic of Moldova for 0-6 years) and the number of children enrolled in institutions. Applying the same parametric method of link determination, it is also found in the case of the two variables that there is a direct link for both spatial areas taken in the analysis. The increase by 10 persons of the population has an average increase in the number of children enrolled in 4 persons in Bacau County, while at the level of the Central Region of the Republic of Moldova the increase with a child from the official age group would lead to an increase on average with a child enrolled in early education institutions.

As can be seen from figure no. 12, the determinant coefficient calculated for Bacau County data shows an influence of $90.6 \%$ of the population of the official age group on the number of children enrolled in the early education system, while for the situation of the Central Region of the Republic of Moldova the influence is only 59.6\%.
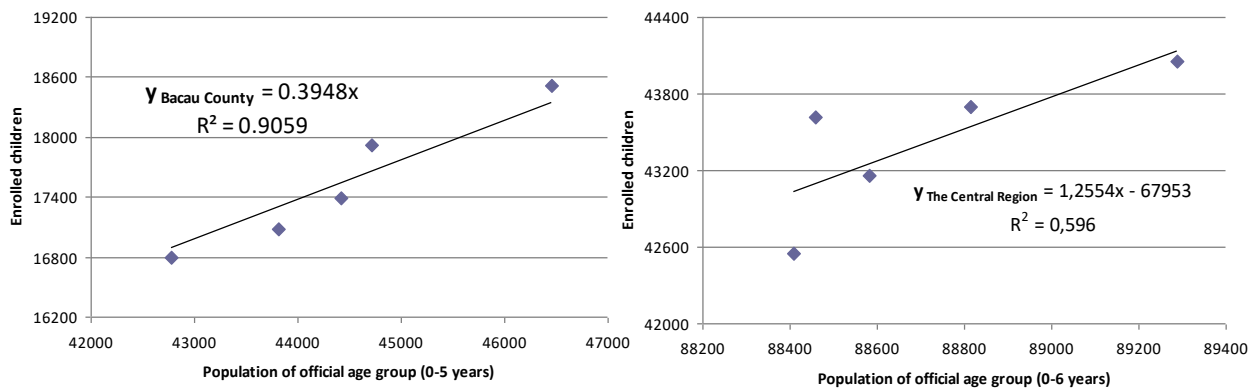

Figure 12: The existing link between the population of the official age group and the number of children enrolled in the early education institutions in Bacau County and the Central Region of the Republic of Moldova

Source: processed data from County Statistical Direction Bacau database and www.statistica.md

\section{Conclusion}

The analysis of indicators characterizing the situation recorded in early education system of Bacau County in Romania, as well as that of the Central Region of the Republic of Moldova, represented the main objective of this research.

Based on the data above, we can conclude that the evolution of number of nurseries and kindergartens in Bacau County was not a favourable one, as the value of this indicator decreases from year to year, whereas in the Central Region it registers an ascending trajectory, being on a rising trend in the 2013-2016 period, but with a slight decrease in 2017 compared to previous year.

The year over year decrease in the population aged 0-5 years in Bacau County in the 2013-2017 period also triggered a decrease in the number of enrolled children in nurseries and kindergartens in the county, whereas the growth of population aged 0-6 years in the Central Region of the Republic of Moldova triggered an increase in the number of enrolled children in early education units in this region.

The gross enrollment rate in early childhood education and preprimary education in Bacau County is lower than that of the Central Region of the Republic of Moldova, fluctuating from year to year, but without exceeding $40 \%$, while in the Central Region 
the gross enrollment rate is on a rising trend from year to year, reaching a peak of $49.3 \%$ in 2016 and 2017.

The average unit size in early education in the Central Region is higher than in Bacau County, with an average of 90 children per nursery/kindergarten compared to an average of only 39 children per unit in Bacau County.

The number of teaching staff in the Central Region was significantly higher than in Bacau County, the dynamics of this indicator following an upward trend throughout the analysed period, while the continuous decrease in the number of enrolled children and the population of official age group corresponding to early education level in Bacau County also determined a decrease in the number of teaching staff from year to year. The average number of teaching staff members per unit is only 2 for the situation registered in Bacau County, with 5 persons below the average number of teaching staff members per nursery/kindergarten in the Central Region.

The average number of children per teaching staff member in nurseries and kindergartens in Bacau County is 12, whereas the average number of children per teaching staff member in the Central Region of the Republic of Moldova throughout the entire analysed period is 16 .

The determination of the linear regression parameters for determining the existence of a link between the number of children enrolled in the early education institutions and the teaching staff in this educational system indicates both in Bacau County and the Central Region a direct link, with influences of $85 \%$ in the case of Bacau County and over $90 \%$ in the case of the Central Region. Practically, with the increase of 100 children enrolled in the early education institutions in Bacau County, the number of teaching staff involved would increase on average by 6 teachers, while for the Central Region of the Republic of Moldova, with the increase of 100 children, the staff didactic would increase on average by about 8 people.

Also, when applying the regression model for the variables: the population of official age group and the enrolled children, there is a direct link between them, but with a lower intensity, the coefficient of determination in the Bacau County being slightly higher than that in the Center Region.

\section{References}

INS, Statistics available at www.insse.ro - Tempo-online Database

BNS, Statistic available at www.statistica.md

Baza de date a Direcției Județene de Statistică Bacău

INS, "Sistemul educational în România - Date sintetice", Ediția 2018, București, pag. 16

BNS, “Educația în Republica Moldova - Publicație Statistică”, Ediția 2018, Chișinău, pag. 5

Andrei, Tudorel (2003), Statistică şi econometrie, Ed. Economică, Bucureşti

Jaba, Elisabeta (2003), Statistica, Ed. Economică, Bucureşti 